\begin{tabular}{|l|l|l||}
\hline \multicolumn{2}{|c|}{ PublisherInfo } \\
\hline \hline PublisherName & $:$ & BioMed Central \\
\hline \hline PublisherLocation & $:$ & London \\
\hline \hline PublisherImprintName & $:$ & BioMed Central \\
\hline \hline
\end{tabular}

\title{
Use of portable ultrasound for difficult central venous access
}

\begin{tabular}{||l|l|l||}
\hline \multicolumn{2}{|c||}{ ArticleInfo } \\
\hline \hline ArticleID & $:$ & 4123 \\
\hline \hline ArticleDOI & $:$ & $10.1186 /$ ccf-1999-542 \\
\hline \hline ArticleCitationID & $:$ & 542 \\
\hline \hline ArticleSequenceNumber & $:$ & 60 \\
\hline \hline ArticleCategory & $:$ & Paper Report \\
\hline ArticleFirstPage & $:$ & 1 \\
\hline \hline ArticleLastPage & $:$ & 3 \\
\hline \hline & $:$ & RegistrationDate : 1999-6-7 \\
ArticleHistory & $:$ & OnlineDate $:$ 1999-6-7 \\
\hline \hline ArticleCopyright & $:$ & Current Science Ltd1999 \\
\hline \hline ArticleGrants & $:$ & \\
\hline \hline ArticleContext & $:$ & 130541111 \\
\hline \hline
\end{tabular}




\section{Keywords}

Cannula intravascular, equipment, measurement techniques, ultrasound

\section{Comments}

This study evaluates a familiar technique but not one used by most critical care physicians. It appears from this small group studied to be useful, easy to learn and reduces the complication rate in 'difficult' patients. Their classification of likely difficult venous access is a useful aide memoir.Ultrasound insertion of central venous catheters would be of particular use on ICUs where long-stay patients often become a 'challenge' for venous line insertion.

\section{Introduction}

Most intensive care (ICU) patients have a central venous catheter inserted during their admission. However, insertion is not without its risks, including the risk of failure. Failure rate in a prospective study by Mansfield et al ( $N$ Engl J Med 1994, 331:1735-1738 was found to be 12\% and the complication rate $10 \%$. Ultrasound guidance may avoid both these problems and portable ultrasound machines make this technique possible on the ward. It would be prudent to be able to identify any 'difficult' patients, in whom the operator may anticipate difficulty in central venous catheter insertion, and select them for insertion under ultrasound control.Ultrasound uses high frequency sound waves $(2-10 \mathrm{MHz})$. The sound is reflected at interfaces of tissues of different impedance and is seen as a bright echo. Fluids, such as blood, transmit sound almost completely and is seen as dark. Methods used to identify veins include their non-pulsatile appearance, non-compressibility and distension on head-down tilt.

\section{Aims}

The study had two aims. First, to establish a list of patient criteria for anticipated 'difficult' access. Second, to assess the use of portable ultrasound in these 'difficult' patients. 


\section{Methods}

Over a period of 6 months, 33 patients were referred to the authors for central venous catheterisation from several disciplines in a teaching hospital. They were referred due to previous failure, complications or anticipated difficulty. The patients were entered into the study if they met one of the criteria for difficult venous access listed in the paper. The patient was then examined by ultrasound probe supine, in the neutral position, and the patency, distensibilty and presence of thrombus noted. In some patients the site was marked and another clinician inserted the catheter. Other catheters were inserted using real-time ultrasound imaging. Standard central venous catheterisation kits were used in the study.

\section{Results}

Of the 33 patients in the study, 14 had three or more criteria for anticipated difficulty. The commonest reasons for difficulty included previous difficult catheterisation, limited sites, previous complication and difficult landmarks. Using the ultrasound probe, all 33 patients had an optimal site for catheterisation identified.In 22 patients, real-time ultrasound was used and the catheters inserted successfully. In the nine where the site was marked for cannulation, the insertion was unsuccessful in only three. In this group of patients the catheter was successfully inserted when real-time ultrasound was used. No complications were caused during insertion.

\section{Discussion}

The use of ultrasound and, in particular, real-time ultrasound enabled central venous catheters to be inserted successfully in this group of 'difficult' patients. The authors had considered randomising the patients to ultrasound or conventional techniques but felt that, as these patients had been referred because of anticipated difficulty, it would be unethical. They commented that the technique was easy to learn. For real-time insertion of central venous catheters the longitudinal view was found to be more useful.

\section{References}

1. Hatfield A, Bodenham A: Portable ultrasound for difficult central venous access. Br J Anaesth. 1999, 82: 822-826. 